\title{
PERSEPSI PETANI RAKYAT TERHADAP PERAN PENYULUHAN PERKEBUNAN DI DESA SUNDATA KECAMATAN LUBUK SIKAPING KABUPATEN PASAMAN
}

\author{
Perception of People's Farmers on the Role of Extension of Plantation \\ in Sundata Village, Lubuk Sikaping District, Pasaman Regency
}

\author{
Nadia Martin Nella, Cepriadi, Evy Maharani \\ Program Studi Magister Agribisnis Fakultas Pertanian Universitas Riau, \\ Jl.Bina Widya No.30 Simpang Baru Tampan Pekanbaru \\ E-mail: nadiaagribisnis2303@yahoo.com \\ [Diterima: Oktober 2016; Disetujui: Januari 2017]
}

\begin{abstract}
Economic development in the agricultural sector has a very important role in the economy of developing countries, especially Indonesia which contributed most to the national development. It is understood that the welfare of farmers and rural communities will increase, which will ultimately improve the standard of living in most people and would enhance the overall national income. The purpose of this study was to determine the counseling implementation cocoa plantations in the village of Lubuk Sikaping Sundata District of Pasaman District, as well as to analyze the perception of the role of smallholder farmers in the village extension Sundata District of Lubuk Sikaping Pasaman district. This research was conducted in the District of Lubuk Sikaping Kanagarian Sundata, Pasaman District, with the consideration that Kanagarian Sundata needs counseling role for cocoa communities using survey methods. In this study, the sampling technique used (Proportionate Random Sampling), the sampling of members of the population at random and proportional. The population of farmer groups of 138 people, so by using the formula Slovin obtained as many as 57 respondents. The results showed that the implementation of the extension in Kanagarian Sundata can generally be said to be doing well because of compliance with elements of counseling. Farmer's perception of the role of agricultural extension officers in their duties categorized as "instrumental" well. Recapitulation of farmers' perceptions of the role of educator average number of seven factors: 2.53 with the category of "acts". The lowest score by category "no role" that is the perception of the role of educator as education and dissemination of information/innovation, while the perception of the role of educator as a facilitator, consultant, coaching, monitoring, and evaluation has the highest score by category "topic" well.
\end{abstract}

Keywords: Perception, Farmer People, Roles Extension Plantation

\begin{abstract}
ABSTRAK
Pembangunan ekonomi di sektor pertanian memiliki peran yang sangat penting dalam perekonomian negara-negara berkembang, khususnya Indonesia yang berkontribusi paling besar terhadap pembangunan nasional. Dipahami bahwa kesejahteraan petani dan masyarakat pedesaan akan meningkat, yang pada akhirnya akan meningkatkan standar hidup pada kebanyakan orang dan akan meningkatkan pendapatan nasional secara keseluruhan. Tujuan dari penelitian ini adalah untuk mengetahui pelaksanaan penyuluhan perkebunan kakao di Desa Lubuk Sikaping Kabupaten Sundata Kabupaten Pasaman, serta untuk menganalisis persepsi peran petani kecil dalam penyuluhan desa Sundata Kecamatan Lubuk Sikaping Kabupaten Pasaman. Penelitian ini dilakukan di Kecamatan Lubuk Sikaping Kanagarian Sundata, Kabupaten Pasaman, dengan pertimbangan Kanagarian Sundata sangat memerlukan peran konseling bagi masyarakat kakao dengan menggunakan metode survei. Dalam penelitian ini, teknik pengambilan sampel yang digunakan (Proportionate Random Sampling), yaitu pengambilan sampel anggota populasi secara acak dan proporsional. Populasi kelompok tani sebanyak 138 orang, sehingga dengan menggunakan rumus Slovin diperoleh sebanyak
\end{abstract}


57 responden. Hasil penelitian menunjukkan bahwa implementasi ekstensi di Kanagarian Sundata secara umum dapat dikatakan berjalan dengan baik karena kepatuhan dengan unsur-unsur konseling. Persepsi petani tentang peran petugas penyuluh pertanian dalam tugas mereka dikategorikan sebagai sumur "instrumental". Rekapitulasi persepsi petani tentang peran pendidik rata-rata berjumlah tujuh faktor: 2,53 dengan kategori "tindakan". Skor terendah berdasarkan kategori "tidak ada peran" yaitu persepsi peran pendidik sebagai pendidikan dan penyebaran informasi / inovasi, sedangkan persepsi peran pendidik sebagai fasilitator, konsultan, pembinaan, pemantauan, dan evaluasi memiliki tertinggi skor menurut kategori "beperan" dengan baik.

\section{Kata kunci: Persepsi, Petani, Peran Penyuluhan Perkebunan}

\section{PENDAHULUAN}

Pembangunan ekonomi di sektor pertanian mempunyai peranan yang sangat penting dalam perekonomian negara yang sedang berkembang terutama Indonesia yang memberi sumbangan terbesar pada pembangunan nasional. Hal ini diartikan bahwa kesejahteraan petani dan masyarakat pedesaan akan meningkat, yang pada akhirnya akan meningkatkan taraf hidup di sebagian besar masyarakat serta akan meningkatkan pendapatan nasional secara keseluruhan.

Sektor perkebunan kakao merupakan salah satu sektor yang saat ini menduduki sektor penting dan menjadi sektor unggulan perkebunan di Sumatera Barat. Khususnya di Sumatera Barat, Kakao merupakan komoditas primadona yang banyak diusahakan oleh masyarakat dan badan usaha. Kakao adalah komoditi yang perkembangannya sangat cepat dan peningkatan dalam ekonomi yang selalu meningkat.

Berdasarkan data Badan Statistik (BPS) Pada tahun 2009 produksi kakao di Pasaman sebanyak $6.923 \mathrm{Kg}$, dengan perkembangan yang memiliki petani yang sangat merawat perkebunan kakao dengan baik. Kakao merupakan tanaman unggulan Pasaman dengan peningkatan produksi setiap tahunnya. Pada tahun 2010 produksi kakao di Pasaman kembali meningkat dengan produksi $7.269 \mathrm{Kg}$, melihat angka produksi selalu meningkat, maka Pemerintah Sumatera Barat memberikan progam untuk perkembangan kakao di Pasaman setiap tahunnya dalam bentuk memberikan jutaan bibit unggul kakao, diberikan secara gratis kepada petani untuk ditanam di lahan perkebunan yang mereka milliki. Program ini di biayai oleh APBD Provinsi, APBN maupun APBD Kabupaten.
Produksi kakao di Pasaman tercatat mencapai 14.409 ton dan upaya peningkatan produksi dan mutu dilakukan dengan program gerakan nasional melalui tiga kegiatan yakni peremajaan, rehabilitasi, dan intensifikasi yang dimulai sejak tahun 2010. Kegiatan peremajaan lahan dilakukan pada tanaman kakao yang sudah berusia 20 tahun dengan bantuan bibit dan pupuk yang diberikan oleh ketua kelompok petani komoditi kakao.

Sementara itu, kegiatan rehabilitasi tanaman kakao pada tahun 2011 dilakukan pada lahan seluas 200 hektare, sedangkan kegiatan intensifikasi pada kebun kakao seluas 400 hektare. Dalam pelaksanaan program para petani dibantu dengan Rp.750 ribu/hectare kebun kakao, sehingga dapat melaksanakan kegiatan dengan kriteria yang telah ditetapkan pemerintah (Dinas Perkebunan Pasaman, 2012).

Kabupaten Pasaman merupakan daerah unggulan kakao terbaik dan menghasilkan kakao yang unggul dan berkualitas. Perkembangan perkebunan kakao ini tidak lepas dari harapan dan peluang yang akan diraih pada aktivitas usahatani kakao itu tersebut. Bagi masyarakat Kabupaten Pasaman sampai saat ini usaha perkebunan kakao merupakan alternatif untuk merubah perekonomian masyarakat, karena itu kegiatan masyarakat terhadap pembangunan perkebunan kakao ini masih tinggi.

Petani kakao merupakan pelaku utama dalam mempengaruhi keberhasilan perkembangan dan pembangunan perkebunan kakao di Pasaman. Khususnya pada petani swadaya yang menghadapi permasalahan yang sering terjadi, dari pada dibandingkan dengan petani yang berbadan usaha. Terkadang permasalahan yang dihadapi oleh petani swadaya itu adalah seperti : Pengadaan sarana, Teknik budidaya, pengolahan dan pemasaran hasil produksi. 
Kondisi tersebut membuat petani sangat membutuhkan informasi teknik, informasi pasar, bantuan permodalan dan sebagainya, sehingga penting diadakannya penyuluhan di Kecamatan Sundata Kabupaten Pasaman untuk membimbing, memotivasi, dan membina petani, serta mencarikan solusi terhadap permasalahan yang sering di hadapi oleh petani. Peran penyuluh akan merubah perilaku petani baik dari aspek pengetahuan, sikap dan keterampilan, sehingga mampu membawa petani kakao pada tujuan penyuluhan yaitu: berusahatani lebih baik( better farming), berbisnis lebih baik (better bussiness), dan hidup yang lebih baik (better living).

Secara garis besar petani kakao dalam perkebunan rakyat dapat dikelompokan menjadi dua, yaitu petani kakao swadaya dan plasma. Petani kakao yang ada di Pasaman dicirikan oleh keterikatan secara kredit memiliki petani kakao swadaya, disebabkan Pasaman tidak memiliki pabrik pengolahan kakao itu tersebut, maka petani yang ada di Pasaman hanya petani kakao swadaya saja. Petani swadaya hanya mengolah kebun sendiri, diorganisasikan sendiri, dibiayai sendiri, hasil dipasarkan sendiri, dan tidak terikat dengan perkebunan atau pabrik kakao manapun.

\section{A. Rumusan Masalah}

Berdasarkan informasi dari para petani yang ada di kenagarian Sundata, bahwa pada tahun 2010 perkebunan kakao yang ada di Sundata mengalami masalah yang mengakibatkan rendahnya hasil produksi kakao, rendahnya produksi kakao disebabkan oleh serangan penyakit terhadap kakao, para petani mengungkapkan bahwa penyakit yang menyerang kakao ini adalah penyakit jamur hitam. Penyakit jamur hitam ini mengalami sebagian kakao mati, berproduksi rendah, dan menyebarkan ke perkebunan petani lainnya.

Berdasarkan uraian diatas peneliti tertarik untuk melakukan penelitian bagaimana persepsi petani rakyat terhadap pentingnya peran penyuluhan perkebunan kakao dan permasalahan penelitian yang dapat dirumuskan sebagai berikut :

1. Bagaimana penyelenggaraan penyuluhan perkebunan kakao di Desa Sundata Kecamatan Lubuk Sikaping Kabupaten Pasaman?
2. Bagaimana persepsi kelompoktani kakao terhadap peran penyuluhan di Desa Sundata Kecamatan Lubuk Sikaping Kabupaten Pasaman?

\section{B. Tujuan dan Manfaat Penelitian}

\section{Tujuan Penelitian}

Persepsi petani rakyat terhadap pentingnya kegiatan penyuluhan perkebunan kakao di Desa Sundata Kecamatan Lubuk Sikaping Kabupaten Pasaman tidak terlepas dari peranan penyuluhan. Untuk itu dari penelitian ini yaitu :

a. Mengetahui penyelenggaraan penyuluhan perkebunan kakao di Desa Sundata Kecamatan Lubuk Sikaping Kabupaten Pasaman.

b. Menganalisis persepsi petani rakyat terhadap peran penyuluhan di Desa Sundata Kecamatan Lubuk Sikaping Kabupaten Pasaman.

\section{Manfaat Penelitian}

Penelitian ini juga memiliki manfaat yang dapat dijabarkan sebagai berikut:

a. Sebagai bahan informasi bagi mahasiswa yang membutuhkan penelitian sejenis maupun lanjut.

b. Sebagai bahan masukan bagi lembagalembaga pelayanan masyarakat dan instansi terkait serta bagi pemerintah dalam mengambil kebijakan, khususnya yang berhubungan dengan kegiatan penyuluhan di Kabupaten Pasaman.

c. Sedangkan bagi penulis sendiri dapat menambah pengetahuan

\section{METODOLOGI PENELITIAN}

\section{Tempat dan Waktu Penelitian}

Penelitian ini dilaksanakan di Kanagarian Sundata Kecamatan Lubuk Sikaping, Kabupaten Pasaman, dengan pertimbangan bahwa Kanagarian Sundata sangat memerlukan peran penyuluhan bagi perkebunan kakao masyarakat. Alasan memilih lokasi ini sebagai penelitian dengan pertimbangan, bahwa usaha Perkebunan kakao merupakan mata pencaharian utama masyarakat dan di daerah ini 
juga terdapat pengelolaan produksi kakao menjadi bubuk kakao atau pasta yang terbuat dari biji kakao. Waktu pelaksanaan penelitian ini dimulai Bulan Agusutus 2014 sampai Bulan Mei 2015, dengan kegiatan meliputi survey tempat, pengumpulan data awal, penyusunan proposal dan pengumpulan data untuk hasil penelitian.

\section{Teknik Pengambilan data dan Sumber Data}

Data yang dikumpulkan dalam penelitian meliputi data primer dan data sekunder. Data primer merupakan data diperoleh langsung dari lapangan melalui wawancara dengan petani sampel (petani rakyat) menggunakan daftar nama yang telah disediakan. Data primer meliputi identitas sampel petani rakyat, kelompok tani, serta informasi lain yang dibutuhkan dalam penelitian yang akan datang. Data skunder merupakan data diperoleh dari instansi kelembagaan terkait dengan Dinas Perkebunan Pasaman, Biro Pusat Statistik (BPS) Balai Penyuluhan Pertanian (BPP) Kecamatan Lubuk Sikaping serta data penunjang lainnya yang diperoleh dari data statistik, publikasi penelitian bebagai literatur yang diperoleh dari data statistik, publikasi penelitian dan jurnal serta sumber atau media sosial yang berhubungan dan menunjang penelitian ini.

Dalam media sosial data yang digunakan beberapa teknik diantaranya :

a. Wawancara sistematik yaitu proses memperoleh untuk tujuan penelitian dengan cara tanya jawab sambil bertatap muka antara pewawancara (peneliti) dengan responden dengan berpedoman pada kuisioner yang merupakan serangkaian daftar pertannyaan yang disusun secara sistematik dengan tujuan penelitian yang ingin dicapai.

b. Observasi langsung yaitu pengamatan yang dilakukan secara langsung pada objek yang diobservasi memfokuskan pada kegiatan penyuluhan dan persepsi petani rakyat terhadap kegiatan penyuluhan yang telah dilakukan. Pendataan dilakukan guna melengkapi data primer yang diperoleh dari wawancara. c. Studi Kepustakaan dan Dokumentasi yaitu mempelajari berbagai bahan-bahan bacaan yang seperti buku, jurnal ilmiah, dokumen,

panduan, dan laporan pelaksaan kegiatan penyuluhan kepada petani rakyat serta profil Kabupaten, Kecamatan dan Desa yang menjadi lokasi Penelitian.

d. Penelusuran data online yaitu dengan melaksanakan penelusuran data dan informasi melalui media jaringan internet, sehingga dapat memanfaatkan data dan dapat dipertanggung jawabkan secara akademis.

\section{Metode Penelitian dan Pengambilan Sampel}

Metode yang digunakan dalam penelitian ini adalah: metode survei yaitu turun ke lapangan dan melakukan pengamatan dengan mendapatkan data dan informasi yang lengkap yang berhubungan dalam penelitian ini. Dalam penelitian ini teknik pengambilan sampel yang digunakan (Proportionate Random Sampling), yaitu pengambilan sampel dari anggota populasi secara acak dan proporsional.

Besar sampel dalam penelitian ini dapat dihitung dengan menggunakan rumus Slovin dalam Damro (2011) apabila populasi sudah diketahui terlebih dahulu.

Untuk dapat mengetahui hubungan antara persepsi penyuluh dengan pentingnya penyuluhan perkebunan dapat mengukur kategori tersebut menggunakan rumus interval, yaitu: Populasi dari kelompok tani sebesar 138 orang, jadi dengan menggunakan rumus Slovin besar sampel dalam penelitian ini hanya di ambil sebanyak 57 orang dari populasi, untuk mempermudah di lapangan sampel diambil masing-masing kelompok yang mewakili populasi sesuai tujuan penelitian.

Berdasarkan tabel 1. Kelompok tani yang memiliki jumlah petani yang paling banyak adalah kelompok tani sahabat dengan jumlah petani 63 orang, sedangkan kelompok tani yang memiliki jumlah petani yang paling sedikit adalah kelompok tani hidup baru dengan jumlah petani 15 orang. Kriteria sampel dalam penelitian ini merupakan anggota yang di ambil dari beberapa sampel yang aktif dalam kelompok tani tersebut. 
Serta merupakan petani kakao yang aktif dalam budidaya tanaman kakao.Para petani yang menjadi sampel penelitian ini, bersedia mengisi kuisioner dan bersedia diwawancarai.

Tabel 1. Nama-nama yang dijadikan sampel dalam kelompok

\begin{tabular}{cccccc}
\hline No & Kelompok Tani & $\begin{array}{c}\text { Komoditi yang } \\
\text { di Tanam }\end{array}$ & $\begin{array}{c}\text { Jumlah Petani } \\
\text { (orang) }\end{array}$ & $\begin{array}{c}\text { Jumlah } \\
\text { Sampel }\end{array}$ & Persentase (\%) \\
\hline 1 & Harapan & Kakao & 28 & 12 & 21,05 \\
2 & Sahabat & Kakao & 63 & 26 & 45,61 \\
3 & Lestari & Kakao & 32 & 13 & 22,81 \\
4 & Hidup Baru & Kakao & 15 & 6 & 10,53 \\
\hline & Total & & 138 & 57 & 100 \\
\hline
\end{tabular}

Sumber : Gapoktan Sundata (2015)

Pada kelompok Harapan terdapat jumlah petani sebanyak 28 orang dan sampel yang diambil sebanyak 12 sampel yang dipilih secara acak, dengan persentase 21,05\%. Kelompok Sahabat memiliki anggota sebanyak 63 orang petani, dan sampel yang diambil berjumlah 26 sampel, dengan persentase $45,61 \%$.

Kelompok Lestari memiliki anggota sebanyak 32 orang dan sampel yang diambil sebanyak 13 sampel dengan persentase $22,81 \%$. Kelompok tani hidup baru memiliki 15 anggota dan sampel yang diambil sebanyak 6 sampel dengan persentase $10,53 \%$.

\section{Metode Pengumpulan Data dan Sumber Data}

Dalam penelitian ini pengumpulan data dilakukan dengan menggunakan metode survei. Data dikumpulkan dengan menggunakan kuesioner yaitu dengan memberikan daftar pertanyaan terstruktur yang disesuaikan dengan materi penelitian. Data yang dikumpulkan dalam penelitian ini adalah data primer dan data sekunder.

\section{a. Data Primer}

Pengumpulan data primer dilakukan dengan wawancara yang diperoleh secara langsung dari anggota Gapoktan yang menjadi sampel, dengan menggunakan daftar kuisioner maupun pengamatan langsung di lapangan. Dalam penelitian ini bentuk kuisioner yang dipakai adalah bentuk kuisioner tertutup yaitu kuisioner yang sudah disediakan alternatif jawaban sehingga responden tinggal memilih alternatif jawaban yang tersedia, sedangkan metode wawancara digunakan untuk mendapatkan informasi guna melengkapi data yang diperoleh dari dokumen. Data primer yang telah dikumpulkan meliputi identitas sampel, keadaan sosial (tingkat pendidikan), keadaan ekonomi (besarnya pendapatan, simpanan, pinjaman, serta luas usahatani).

\section{b. Data Sekunder}

Data sekunder diperoleh dari Kelurahan, BPS, Kecamatan dan pengurus Gapoktan. Metode dokumentasi adalah suatu cara untuk memperoleh data atau informasi tentang hal-hal yang ada kaitannya dengan penelitian dengan jalan melihat kembali sumber tertulis baik berupa angka atau keterangan. Data dokumentasi diperoleh dari instansi yang ada kaitannya dengan penelitian ini meliputi: Perkembangan petani setelah adanya penyuluh yang masuk kedesa Sundata (iklim, keadaan geografi, kependudukan), maupun dari literatur lain yang dianggap perlu untuk mendukung penelitian ini. Hal ini dilakukan untuk melihat Persepsi Petani kakao rakyat terhadap peran penyuluhan perkebunan kakao di Desa Sundata Kecamatan Lubuk Sikaping Kabupaten Pasaman.

\section{Analisis Data}

Analisis data yang digunakan penulis dalam penelitian ini adalah metode deskriptif, yaitu suatu metode atau cara menganalisa dan menguraikan data-data penelitian yang ada, selanjutnya dikaitkan dengan teori-teori yang ada hubungannya dengan permasalahan guna menarik suatu kesimpulan yang disajikan. Data yang diperoleh terlebih dahulu ditabulasi sesuai 
dengan tujuan penelitian. Untuk mendeskripsikan variabel peran penyuluhan perkebunan kakao di desa Koto Tinggi digunakan skala ordinal yaitu dengan berpedoman pada Skala Likert.

Skala likert adalah skala yang digunakan untuk mengukur sikap, pendapat, dan persepsi seseorang atau sekelompok orang tentang fenomena sosial. Dalam penelitian, fenomena sosial ini telah ditetapkan secara spesifik oleh peneliti yang selanjutnya disebut sebagai variabel penelitian (Sugiyono, 2009). Dengan skala likert, maka variabel yang akan diukur dijabarkan menjadi indikator variabel. Kemudian indikator tersebut dijadikan sebagai titik tolak untuk menyusun item-item instrumen yang dapat berupa pertanyaan atau pernyataan.

Pokok-pokok skala memakai alternatif jawaban:
a. Kurang Berperan : dengan skor 1
b. Cukup Berperan : dengan skor 2
c. Berperan
: dengan skor 3

Dari total nilai pokok-pokok skala tersebut dikelompokkan menjadi 3 kategori yaitu terlaksana, kurang terlaksana, dan tidak terlaksana, untuk menentukan kategori persepsi petani terhadap peran penyuluh pertanian dalam perkembangan Program WKP.

Untuk dapat mengetahui hubungan antara persepsi penyuluh dengan pentingnya penyuluhan perkebunan dapat mengukur kategori tersebut menggunakan rumus interval, yaitu:

Rentang Skala $=\frac{\text { Skala Tertinggi-Skala Terendah }}{\text { Banyak Skala }}-0,01$

Rentang penilaian berkisar $1-5$, yaitu penilaian tertinggi . Rentang skala pada penelitian ini dihitung sebagai berikut:

$$
\mathrm{n}=\frac{\mathrm{N}}{1+\mathrm{N} \cdot \mathrm{e} 2}
$$

Keterangan

$\begin{array}{ll}\mathrm{n} & \text { : Jumlah Sampel } \\ \mathrm{N} & \text { : Jumlah Populasi } \\ \mathrm{e} 2 & \text { : Presisi (ditetapkan } 10 \% \text { dengan } \\ & \text { tingkat kepercayaan 90\%) }\end{array}$

Tabel 2. Variabel dan Indikator Peran Penyuluh

\begin{tabular}{|c|c|c|}
\hline Variabel & Sub variabel & Indikator \\
\hline \multirow[t]{7}{*}{ Peran Penyuluh } & Sebagai Edukasi* & $\begin{array}{l}\text { 1. Melaksanakan pelatihan usaha perkebunan kakao } \\
\text { 2. Meningkatkan pengetahuan petani budidaya kakao } \\
\text { 3. Memberikan materi penyuluh yang sesuai dengan kebutuhan } \\
\text { petani }\end{array}$ \\
\hline & $\begin{array}{l}\text { Sebagai Diseminasi } \\
\text { Informasi/inovasi } \\
* *\end{array}$ & $\begin{array}{l}\text { 1. Memberikan bimbingan teknis tentang usaha agribisnis pedesaan. } \\
\text { 2. Memperkenalkan teknologi baru kepada petani } \\
\text { 3. Memberikan teknik budidaya terbaru dan berkelanjutan } \\
\text { 4. Membantu petani dalam mengambil keputusan yang segera } \\
\text { memerlukan penanganan }\end{array}$ \\
\hline & $\begin{array}{l}\text { Sebagai } \\
\text { pendampingan }\end{array}$ & $\begin{array}{l}\text { 1. Membantu memfasilitasi kemudahan akses terhadap sarana } \\
\text { produksi, teknologi dan pasar } \\
\text { 2. Mengambil keputusan mengenai masalah dan kendala yang } \\
\text { dihadapi kelompok }\end{array}$ \\
\hline & $\begin{array}{l}\text { Sebagai } \\
\text { Konsultasi*** }\end{array}$ & $\begin{array}{l}\text { 1. Membantu memecahkan masalah yang dihadapi petani } \\
\text { 2. Memberikan alternatif pemecahan masalah kepada petani } \\
\text { 3. Membantu Gapoktan selama selama penyusunan dokumen WKP }\end{array}$ \\
\hline & Sebagai pembinaan & $\begin{array}{l}\text { 1. Bersama PMT, memberikan pembinaan dalam pemanfaatan dan } \\
\text { pengelolaan dana BLM WKP (wilayah kerja penyuluh) } \\
\text { 2. Menjalin kerjasama dengan kelompoktani dan instansi lembaga } \\
\text { yang terkait untuk meningkatkan SDM }\end{array}$ \\
\hline & $\begin{array}{l}\text { Sebagai } \\
\text { Pemantau }\end{array}$ & $\begin{array}{l}\text { 1. Melakukan pemantauan potensi ekonomi desa yang berbasis } \\
\text { usaha pertanian. } \\
\text { 2. Melakukan pemantauan kegiatan terhadap kegiatan kelompoktani. }\end{array}$ \\
\hline & Sebagai evaluasi & $\begin{array}{l}\text { 1. Membantu Gapoktan membuat laporan perkembangan WKP } \\
\text { 2. Memberikan penilaian terhadap keberhasilan kelompoktani }\end{array}$ \\
\hline
\end{tabular}

Keterangan : (*) menunjukan variabel yang memiliki persamaan peran penyuluhan menurut Mardikanto (2009), yaitu:* Edukasi: $* *$ Diseminasi Informasi atau Inovasi: $* * *$ Konsultan 
Sehingga diperoleh rentang skala penilaian peran penyuluh terhadap pentingnya penyuluhan perkebunan adalah sebagai berikut: Berdasarkan kisaran di atas, maka persepsi petani terhadap peran penyuluh pertanian dalam Program WKP (Wilayah Kerja Penyuluh) secara keseluruhan di bagi 3 yaitu:
a. Kategori cukup berperan
$: 1-1,66$
b. Kategori kurang berperan
$: 1,67-2,33$
c. Kategori berperan
$: 2,34-3,00$

Tentang jenjang rentang (range) skor untuk indeks yang disusun menurut Akbar dan Usman (2009), yang dimaksud dari rentang range ini melihat skor yang tertinggi dan skor terendah, penjabaran setiap skor terhadap peran penyuluhan dan persepsi petani, yang berpengaruh terhadap pentingnya peran penyuluh bagi petani (Tabel 2).

Dalam penelitian ini variabel yang digunakan dalam menentukan persepsi penyuluhan adalah diambil dari peran penyuluhan pertanian sebagai variabel $\mathrm{X}$ yang bersumber dari Mardikanto (2009) yang akan dibandingkan dengan UU No. 16 Tahun 2006, yang apabila ada kesamaan diantara keduanya akan dipilih salah satu menjadi sub-variabel yang akan digunakan, dan yang tidak memiliki kaitan akan tetap dijadikan sub-variabel. Variabel dan Indikator Keberhasilan Program WKP (Wilayah Kerja Penyuluh) dapat dilihat dari beberapa sub variabel, seperti berikut (Tabel 3):

Tabel 3. Indikator Keberhasilan Program WKP (Wilayah Kerja Penyuluh)

\begin{tabular}{lll}
\hline \multicolumn{1}{c}{ Variabel } & \multicolumn{1}{c}{ Sub variabel } & \multicolumn{1}{c}{ Indikator } \\
\hline Keberhasilan & $\begin{array}{l}\text { Indikator Hasil } \\
\text { (Output }) \text { dari } \\
\text { kegiatan WKP }\end{array}$ & $\begin{array}{l}\text { Tersalurnya permodalan sebagai modal untuk melakukan } \\
\text { usaha pertanian. } \\
\text { Terlaksananya fasilitas penguatan kapasitas dan kemampuan } \\
\text { SDM }\end{array}$ \\
\cline { 2 - 3 } & $\begin{array}{l}\text { Meningkatkan kemampuan Gapoktan dalam memfasilitasi dan } \\
\text { mengelola bantuan modal usaha untuk petani. }\end{array}$ \\
& $\begin{array}{l}\text { Dampak } \\
(\text { Outcome }) \text { dari } \\
\text { kegiatan WKP }\end{array}$ & $\begin{array}{l}\text { Meningkatkan jumlah petani,mendapat bantuan modal. } \\
\text { Meningkatnya kegiatan agribisnis di perdesaan. } \\
\text { Meningkatnya pendapatan petani. }\end{array}$ \\
&
\end{tabular}

Sumber : Kementrian Pertanian (2010)

\section{Konsep Operasional}

Dalam menyamakan pengertian terhadap beberapaistilah yang digunakan dalam penelitian ini dijelaskan beberapa konsep operasional, antara lain adalah sebagai berikut:

a. Pengembangan wilayah kerja penyuluh adalah bagian dari pelaksanaan program PNPM-Mandiri melalui bantuan modal usaha dalam menumbuh kembangkan perkebunan sesuai dengan potensi pertanian desa sasaran.

b. Penyuluh pertanian adalah orang yang mengemban tugas untuk memberikan dorongan atau motivasi kerja kepada para petani agar terdorong serta mampu mengubah cara pikir, cara kerja, dan cara hidup maju dengan cara-cara yang lebih baik.

c. Peran penyuluh pertanian adalah sebagai sumber informasi utama bagi petani, dan sebagai jembatan penghubung antara lembaga penelitian dengan petani di dalam melaksanakan kegiatan penyuluhan di Kanagarian Sundata.

d. Peran Penyuluh Edukasi, yaitu untuk memfasilitasi proses belajar yang dilakukan oleh para penerima manfaat penyuluhan (beneficiaries) dan atau stakeholders pembangunan yang lainnya.

e. Peran Penyuluh diseminasi informasi/inovasi, yaitu penyebarluasan informasi/ inovasi dari sumber informasi dan atau penggunaanya. Utamanya yang terkait dengan kebutuhan-kebutuhan masyarakat, pengambilan keputusan kebijakan dan atau pemecahan masalah yang segera memerlukan penanganan.

f. Peran Penyuluh Fasilitasi, atau pendampingan, yang lebih bersifat melayani kebutuhan-kebutuhan yang dirasakan oleh client-nya.Fungsi fasilitasi tidak harus selalu dapat mengambil keputusan, memecahkan masalah, dan atau 
memenuhi sendiri kebutuhan-kebutuhan klien, tetapi seringkali justru hanya sebagai penengah/ mediator.

g. Peran Penyuluh Konsultasi, yang tidak jauh berbeda dengan fasilitasidalam melaksanakan peran konsultasi, penting untuk memberikan rujukan kepada pihak lain yanglebih mampudan atau lebih kompeten untuk menanganinya. Dalam melaksanakan fungsi konsultasi, penyuluh tidak boleh hanya menunggu tetapi harus aktif mendatangi kliennya.

h. Peran Penyuluh Supervisi, atau pembinaanlebih banyak pada upaya untuk bersama-sama klien melakukan penilaian (self assesment), untuk kemudian memberikan saran alternatif perbaikan atau pemecahan masalah yang dihadapi.

i. Peran Penyuluh Pemantauan, yaitu kegiatanpemantauan oleh penyuluh di perkebunan kakao agar lebih menonjolkan peran penilaian, sedang supervisi lebih menonjolkan peranupaya perbaikan.

j. Peran Penyuluh Evaluasi, yaitu kegiatan pengukuran dan penilaian yang dapat dilakukan pada sebelum (formatif), selama (on-going, pemantauan) dan setelah kegiatan selesai dilakukan (sumatif, expost). Meskipun demikian, evaluasi seringkali hanya dilakukan setelah kegiatan selesai, untuk melihat proses hasil kegiatan (output), dan dampak (outcome) kegiatan, yang menyangkut kinerja (performance) baik teknis maupun finansialnya

k. Penyuluh Pendamping adalah penyuluh pertanian yang ditugaskan oleh Bupati/Walikota atau pejabat yang ditunjuk untuk mendampingi petani, kelompoktani dan Gapoktan dalam Pelaksanaan WKP (Wilayah Kerja Penyuluh) di Kenagarian Sundata Kecamatan Lubuk Sikaping Kabupaten Pasaman.

1. Petani merupakan sasaran utama penyuluh, dimana petani merupakan orang yang aktif di dalam melakukan usaha di bidang pertanian tanaman pangan, baik petani yang sudah tergabung dikelompoktani di Kenagarian Sundata Kecamatan Lubuk Sikaping Kabupaten Pasaman.

m. Kelompoktani (Poktan) adalah kumpulan petani/peternak yang dibentuk atas dasar kesamaan kepentingan, kesamaan kondisi lingkungan (sosial, ekonomi, sumber daya) dan keakraban dan mengembangkan usaha anggota.

n. Persepsi adalah proses bagaimana seseorang menyeleksi, mengatur dan menginterpretasikan masukan-masukan informasi untuk menciptakan gambaran keseluruhan yang berarti.

o. Output adalah hasil yang diharapkan dari kegiatan WKP

p. Outcome adalah dampak yang dihasilkan dari terlaksananya kegiatan WKP

\section{HASIL DAN PEMBAHASAN}

\section{Persepsi Petani Terhadap Peran Penyuluh Pertanian}

\section{a. Peran Penyuluh Pertanian}

Penyuluh pertanian merupakan agen perubahan bagi petani yang mendorong petani mengubah prilakunya menjadi petani dengan kemampuan yang lebih baik dan mampu mengambil keputusan sendiri yang selanjutnya akan merubah kehidupan petani yang lebih baik lagi. Melalui peran penyuluh petani diharapkan menyadari akan kebutuhannya melakukan peningkatan kemampuan diri dan berperan di masyarakat dengan lebih baik. Untuk melihat berapa besar atau tingginya peran penyuluh di Kanagarian Sundata dapat dilihat pada (lampiran 2).

\section{1) Persepsi Petani Terhadap Peran Penyuluh Sebagai Edukasi}

Peran penyuluh sebagai pendidik bagi petani yang merupakan sarana proses pembelajaran dengan memfasilitasi petani untuk menanamkan pengertian sikap yang menguntungkan menuju penggunaan aktif mengacu kepada praktek paket teknologi yang lebih baik untuk petani. Peran penyuluh sebagai edukasi dapat dijelaskan pada Tabel 4.

Berdasarkan Tabel 5 dapat dilihat bahwa peran penyuluh sebagai edukasi memiliki ratarata skor variabel 2,32 dengan kategori "kurang berperan". Untuk indikator dalam melaksanakan pelatihan usaha agribisnis, berada pada skor 2,28 kategori "kurang berperan", hal ini disebabkan penyuluh jarang sekali datang untuk mengadakan pelatihan tentang pemahaman budidaya dikarenakan 
akses jalan kurang baik sehingga masingmasing kelompok hanya sekali dikunjungi oleh penyuluh. Jalan merupakan faktor pendukung bagi kemajuan sebuah kegiatan pertanian. Jika akses jalan baik, maka penyuluh pertanian akan lebih mudah dan sering untuk datang ke setiap Poktan memberikan pelatihan yang diinginkan para petani. Maka dari itu perbaikan jalan seharusnya menjadi perhatian utama bagi pemerintah daerah setempat.

Peran penyuluh dalam meningkatkan pengetahuan petani tentang budidaya kakao, diperoleh skor 2,35 dengan kategori 'berperan'. Petani menilai penyuluh secara tidak langsung telah menambah pemahaman petani tentang perkebunan kakao yang baik, mulai dari penyiapan lahan hingga pemanenan hasil kakao dan teknik pemakaian pupuk yang baik dalam perkebunan kakao. Sedangkan dalam penyampaian materi yang sesuai dengan kebutuhan petani, berada pada skor 2,35 kategori "berperan". Materi - materi yang di sampaikan penyuluh benar-benar dibutuhkan oleh petani misalnya demo/kursus cara pembuatan pupuk kompos dan teknik pengendalian hama dan penyakit pada tanaman kakao.

Tabel 4. Persepsi petani terhadap Peran penyuluh sebagai edukasi

\begin{tabular}{|c|c|c|c|}
\hline No & Persepsi anggota & Skor & Kategori \\
\hline 1. & Melaksanakan pelatihan pembibitan kakao & 2,28 & kurang Berperan \\
\hline 2. & Meningkatkan pengetahuan petani tentang budidayapertanian & 2,35 & Berperan \\
\hline 3. & $\begin{array}{l}\text { Memberikan materi penyuluh yang sesuai dengan kebutuhan } \\
\text { petani }\end{array}$ & 2,35 & Berperan \\
\hline & Rata-rata & 2,32 & Berperan \\
\hline
\end{tabular}

Sumber : Data Olahan (2014)

Berdasarkan Tabel 5 dapat dilihat bahwa peran penyuluh sebagai edukasi memiliki ratarata skor variabel 2,32 dengan kategori "kurang berperan". Untuk indikator dalam melaksanakan pelatihan usaha agribisnis, berada pada skor 2,28 kategori "kurang berperan", hal ini disebabkan penyuluh jarang sekali datang untuk mengadakan pelatihan tentang pemahaman budidaya dikarenakan akses jalan kurang baik sehingga masingmasing kelompok hanya sekali dikunjungi oleh penyuluh. Jalan merupakan faktor pendukung bagi kemajuan sebuah kegiatan pertanian. Jika akses jalan baik, maka penyuluh pertanian akan lebih mudah dan sering untuk datang ke setiap Poktan memberikan pelatihan yang diinginkan para petani. Maka dari itu perbaikan jalan seharusnya menjadi perhatian utama bagi pemerintah daerah setempat.

Peran penyuluh dalam meningkatkan pengetahuan petani tentang budidaya kakao, diperoleh skor 2,35 dengan kategori 'berperan'. Petani menilai penyuluh secara tidak langsung telah menambah pemahaman petani tentang perkebunan kakao yang baik, mulai dari penyiapan lahan hingga pemanenan hasil kakao dan teknik pemakaian pupuk yang baik dalam perkebunan kakao. Sedangkan dalam penyampaian materi yang sesuai dengan kebutuhan petani, berada pada skor 2,35 kategori "berperan". Materi - materi yang di sampaikan penyuluh benar-benar dibutuhkan oleh petani misalnya demo/kursus cara pembuatan pupuk kompos dan teknik pengendalian hama dan penyakit pada tanaman kakao.

\section{2) Persepsi Petani Terhadap Peran Penyuluh sebagai diseminasi informasi/inovasi}

Peran penyuluh Diseminasi Informasi/Inovasi merupakan peran seorang penyuluh dalam menyebarkan suatu informasi yang terbaru kepada petani, dimana informasi yang diberikan diharapkan dapat berguna untuk petani dalam meningkatkan produktivitas hasil pertanian. Untuk lebih jelasnya dapat dilihat pada Tabel 5. 
Tabel 5. Persepsi peran penyuluh sebagai diseminasi informasi/inovasi

\begin{tabular}{clcl}
\hline No & \multicolumn{1}{c}{ Persepsi anggota } & Skor & \multicolumn{1}{c}{ Kategori } \\
\hline 1. & Memberikan bimbingan teknis tentang usaha agribisnis & 2,44 & Berperan \\
& perdesaan. & & \\
2. & Memperkenalkan teknologi baru kepada petani & 2,26 & KurangBerperan \\
3. & Memberikan teknik budidaya terbaru dan berkelanjutan & 2,04 & Kurang Berperan \\
4. & Membantu petani dalam mengambil keputusan yang segera & 2,39 & Berperan \\
\hline & memerlukan penangan & 2,28 & Kurang Berperan \\
\hline
\end{tabular}

Pada Tabel 6 dapat dilihat rata-rata skor untuk peran penyuluh sebagai diseminasi informasi/inovasi adalah 2,28 dengan kategori "kurang berperan". Hal ini disebabkan karena kurangnya informasi mengenai teknik terbaru dalam anggota terhadap peran penyuluh dalam memberikan bimbingan teknis tentang usaha agribisnis perdesaan dikategorikan "berperan" dengan skor sebesar 2,44. Penyuluh aktif dan kontinyu dalam melakukan bimbingan kepada petani.

Indikator peran penyuluh dalam memperkenalkan teknologi baru memiliki skor variabel 2,26 dengan kategori "kurang berperan". Teknologi baru yang dapat diperkenalkan oleh penyuluh kepada petani, bisa berupa pengenalan dalam tekknologi pengolahan seperti, mesin pengeringan kakao, mesin pembuatan pasta, sehingga produktifitas pekerjaan dan efesiensi waktu lebih cepat dengan hasil yang baik dari pada tidak mengunakan mesin. Faktor lain penyebab kurang terlaksananya peran penyuluh ini adalah kultur budaya pertanian yang melekat secara turun temurun. Umumnya petani masih ragu/takut menggunakan teknologi baru yang akan diterapkan, karena takut gagal. Faktor biaya juga menjadi kendala dalam penggunaan teknologi baru. Misalnya bibit yang bagus tentunya memiliki harga beli yang mahal dan penemuan alat pertanian yang terbaru tentu akan menggunakan biaya mahal.

Peran penyuluh dalam hal memberikan teknik budidaya terbaru dan berkelanjutan memiliki skor 2,04 dengan kategori "kurang berperan". Biasanya petani perlu melihat sendiri contoh petani lain yang telah sukses menggunakan teknik terbaru tersebut, sehingga mereka yakin dengan menggunakan teknik tersebut. Rendahnya skor peranan penyuluh ini juga karena pengalaman penyuluh yang belum luas dalam hal teknik budidaya terbaru. Tentunya setiap manusia ada keterbatasan dalam penguasaan ilmu, ada spesifikasi bidang ilmu yang dimiliki setiap orang begitu juga penyuluh.

Skor variabel indikator peran penyuluhan dalam hal membantu petani untuk mengambil keputusan yang segera memerlukan penanganan dengan skor 2,39 dengan kategori "berperan".

Permasalahan yang dihadapi petani untuk selanjutnya dibahas oleh para penyuluh dan dicarikan alternatif pemecahan masalahnya. Hal ini menunjukkan bahwa penyuluh sangat tanggap dengan keluhan para petani dalam berusaha tani. Begitu juga petani yang aktif berkonsultasi dengan penyuluh jika terdapat masalah. Hubungan timbal balik yang baik ini sangat membantu untuk perkembangan kemajuan Poktan. Masing - masing baik petani maupun penyuluh memahami perananan yang harus dijalankan.

\section{3) Persepsi Petani terhadap Peran Penyuluh sebagai fasilitasi/ pendampingan}

Peran penyuluh sebagai fasilitasi/pendampingan merupakan melayani kebutuhan-kebutuhan yang dibutuhkan petani, tetapi sering juga penyuluh sebagai penengah/mediator dalam menyelesaikan permasalah yang dihadapi petani dan juga selalu memberikan solusi dalam menyelesaikan masalah, Peran penyuluh sebagai Persepsi peran penyuluh sebagai fasilitasi/pendampingan dapat dijelaskan pada Tabel 6. 
Tabel 6. Persepsi peran penyuluhan sebagai fasilitas/pendamping

\begin{tabular}{clcl}
\hline No & \multicolumn{1}{c}{ Persepsi anggota } & Skor & Kategori \\
\hline 1. & $\begin{array}{l}\text { Membantu memfasilitasi kemudahan akses terhadap } \\
\text { Sarana produksi, teknologi dan pasar }\end{array}$ & 2,75 & Berperan \\
2. & $\begin{array}{l}\text { Mengambil keputusan mengenai masalah dan kendala } \\
\text { yang dihadapi kelompok tani }\end{array}$ & 2,04 & kurang Berperan \\
\hline & Rata-rata & 2,40 & Berperan \\
\hline Sumber : Data Olahan (2014) & &
\end{tabular}

Pada Tabel 6 peran penyuluh sebagai pendamping memiliki rata-rata skor 2,40 dengan kategori "berperan". Hal ini telah dibuktikan oleh para penyuluh.

Dari dua indikator yang diajukan kepada responden, indikator yang memiliki skor tertinggi yaitu pada membantu memfasilitasi kemudahan akses terhadap sarana produksi, teknologi dan pasar dengan skor 2,75 kategori "berperan". Ini tentunya akan memberikan kemudahan kepada para petani untuk memajukan usaha taninya. Penyuluh memberikan informasi tentang cara mendapatkan saprodi pertanian dengan jalan kredit atau lainnya. Indikator dalam hal mengambil keputusan mengenai masalah dan kendala yang dihadapi kelompok memiliki skor 2,04 dengan kategori "kurang berperan". Peran ini tidak hanya sekedar mengambil keputusan mengenai masalah yang dihadapi petani tapi juga sebagai penengah/mediator. Hal ini bukan berarti peran penyuluh tidak ada, tetapi perannya dalam pengambilan keputusan masih kurang.

\section{4) Persepsi Petani Terhadap Peran Penyuluh Sebagai Konsultasi}

Dalam rangka pencapaian tujuan maka diperlukan penyusunan rencana kegiatan yang dapat mengambarkan bagaimana tujuan tersebut dapat dicapai. Ada beberapa hal yang perlu diperhatikan untuk mencapai tujuan tersebut antara lain (BP2KP, 2014):

a. Tingkat kemampuan dari petani dan keluarganya itu sendiri.

b. Sarana dan prasarana penyuluhan pertanian.

c. Situasi lingkup kegiatan penyuluhan pertanian baik fisik maupun non fisik (social, ekonomi, dan budaya).

d. Biaya yang mungkin tersedia.

Dengan memperhatikan permasalahan yang ada pada nagari Sundata maka metode yang dapat digunakan seperti, pendekatan secara kelompok dalam bentuk pertemuan. Peran penyuluh sebagai Konsultasi ialah penyuluh memberikan rujukan kepada pihak lain yang lebih mampu dan atau lebih kompeten untuk menangani masalah-masalah yang dihadapi oleh petani, Persepsi peran penyuluh sebagai konsultasi dapat dilihat tabel 7 .

Tabel 7. Persepsi peran penyuluh sebagai konsultasi

\begin{tabular}{clcl}
\hline No & \multicolumn{1}{c}{ Persepsi anggota } & Skor & Kategori \\
\hline 1 & Membantu memecahkan masalah yang dihadapi petani & 2,79 & Berperan \\
2 & Memberikan alternatif pemecahan masalah kepada petani & 2,98 & Berperan \\
3 & Membantu gapoktan selama selama penyusunan rencana & 2,84 & Berperan \\
& perkembangan perkebunan & 2,87 & Berperan \\
\hline
\end{tabular}

Sumber : Data Olahan (2014)

Pada Tabel 7 dapat dilihat persepsi anggota terhadap peran penyuluh sebagai konsultasi memiliki rata-rata 2,87 dengan kategori "berperan", hal ini dapat dilihat persepsi anggota pada tiap indikator yang diajukan memiliki skor yang cukup tinggi. Ini tentunya peran penyuluh sebagai konsultan terlaksana dengan baik. Masalah-masalah yang dihadapi oleh para petani sudah dapat dipecahkan dengan baik oleh penyuluh, dari tiga indikator yang diajukan kepada anggota, terdapat satu indikator yang memilki skor tertinggi yaitu memberikan solusi dalam pemecahan masalah petani dengan skor 2,98 dan dikategorikan "berperan". Pemecahan masalah yang dilakukan oleh konsultan sangat berpengaruh terhadap peningkatan kualitas usaha tani. Indikator membantu memecahkan 
masalah yang dihadapi petani memiliki skor 2,79 dengan kategori "berperan". Dalam hal ini konsultan berperan untuk membantu memecahkan masalah yang dihadapi petani. Konsultan memberikan solusi setiap masalah yang dihadapi oleh para petani agar kegiatan berjalan dengan lancar.

Mendampingi Gapoktan dalam merencanakan perkembangan perkebunan memiliki skor 2,84 dengan kategori "berperan". Salah satu tugas konsultan dalam pengembangan perkebunan kakao. Dokumen perencanaan ini sangat penting sebagai laporan akhir dari pelaksanaan kegiatan tani. Laporanlaporan ini tentunya memberi pengaruh nanti

kedepannya dalam hal ini penyuluh telah melaksanakan tugasnya dengan baik.

\section{5) Persepsi Petani Terhadap Peran Penyuluh sebagai Supervisi Pembinaan}

Peran penyuluh $r$ sebagai
supervisi/pembinaan merupakan peran
penyuluh bersama-sama kliennya memberikan
penilaian untuk kemudian memberikan saran
anternatif perbaikan atau pemecahan masalah
yang dihadapi oleh petani. Peran penyuluh
sebagai supervisi/pembinaan untuk lebih
jelasnya dapat dilihat pada tabel 8 .

Tabel 8. Persepsi petani terhadap peran penyuluh sebagai supervise/pembinaan

\begin{tabular}{clcc}
\hline No & \multicolumn{1}{c}{ Persepsi anggota } & Skor & Kategori \\
\hline 1. & $\begin{array}{l}\text { Bersama PMT, memberikan pembinaan dalam pemanfaatan } \\
\text { dan pengelolaan dana pemerintah }\end{array}$ & 2,79 & Berperan \\
2. & $\begin{array}{l}\text { Menjalin kerjasama dengan kelompok tani dan instansi } \\
\text { lembaga yang terkait untuk meningkatkan SDM }\end{array}$ & 2,53 & Berperan \\
\hline$\quad$ Rata-rata & 2,66 & Berperan
\end{tabular}

Sumber : Data Olahan (2014)

Berdasarkan Tabel 9 dapat dilihat persepsi anggota terhadap peran penyuluh sebagai pembinaan memiliki rata-rata 2,66 dengan kategori "berperan", hal ini terlihat dari penyuluh yang telah melaksanakan tugasnya sebagai pembina untuk membantu dalam kegiatan tani. Pembina melakukan pelaksanaan terhadap upaya-upaya untuk melakukan penilaian dan memberikan saran-saran alternatif untuk pemecahan yang dihadapi. Penyuluh bersama PMT (Penyelia Mitra Tani) memberikan bimbingan teknis dalam pemanfaatan dan pengelolaan dana dengan skor paling tinggi yaitu 2,79 dengan kategori "berperan". Penyuluh sebagai pembinaan bekerjasama dengan PMT membantu para petani untuk memberikan bimbingan teknis dalam meningkatkan kualitas perkebunan kakao. Petani sangat terbantu dengan adanya bimbingan teknis mengenai bagaimana pemanfaatan dana pemerintah oleh penyuluh yang bekerjasama dengan PMT. Penggunaan dana yang tepat sasaran akan menghindarkan pemborosan dalam penganggaran dana untuk usahatani. Petani juga dapat memiliki keterampilan dalam pembukuan keuangan, sehingga dapat terlihat kemajuan atau kemunduran selama menggunakan dana dari pemerintah tersebut.

Skor untuk menjalin kerjasama dengan kelompoktani dan instansi lembaga yang terkait untuk meningkatkan SDM adalah 2,53 dengan kategori "berperan", hal ini dilakukan untuk meningkatkan kinerja petani. Dalam meningkatkan perkebunan kakao yang sudah seharusnya tugas pembinaan untuk meningkatkan SDM para petani. Salah satu caranya yaitu dengan melakukan kerjasama instansi-instansi seperti Kantor Desa, rumah kelompok tani, BP2KP, dan WKP dalam pengembangan kualitas dan pengetahuan petani. Kemudian adanya studi banding dengan Gapoktan lain juga akan membuat saling tukar informasi dan pengalaman antar petani.

\section{6) Persepsi Petani TerhadapPeran Penyuluh Sebagai Pemantauan}

Pemantauan merupakan evaluasi yang dilakukan selama proses kegiatan sedang berlangsung dengan melakukan penilaian. Pemantauan yang dilakukan oleh penyuluh biasanya melihat keadaan daerah yang berbasis khusus perkebunan kakao, dan juga melakukan 
pemantauan kelompoktani dalam menjalankan tugasnya. Persepsi petani terhadap peran penyuluh sebagai pemantauan dapat dilihat pada Tabel 9.

Tabel 9. Persepsi petani terhadap peran penyuluh sebagai pemantauan

\begin{tabular}{clcc}
\hline No & \multicolumn{1}{c}{ Persepsi anggota } & Skor & Kategori \\
\hline 1. & $\begin{array}{l}\text { Melakukan pemantauan potensi ekonomi desa yang berbasis } \\
\text { khusus perkebunan kakao }\end{array}$ & 2,35 & Berperan \\
2. & $\begin{array}{l}\text { Melakukan pemantauan kegiatan terhadap kegiatan kelompok } \\
\text { tani }\end{array}$ & 2,39 & Berperan \\
\hline & Rata-rata & 2,37 & Berperan \\
\hline Sumber : Data Olahan (2014) & &
\end{tabular}

Berdasarkan Tabel 10 dapat dilihat bahwa persepsi petani terhadap peran penyuluh sebagai pemantauan memiliki rata-rata 2,37 dengan kategori "berperan". Penyuluh dalam pelaksanaan kegiatan sering melakukan pemantauan sebagai evaluasi terhadap kegiatan yang dilaksanakan. Pada indikator identifikasi potensi ekonomi desa yang berbasis khusus perkebunan kakao memiliki skor 2,35 dengan kategori "berperan". Potensi ekonomi yang ada pada usaha tani tersebut belum semua teridentifikasi oleh para penyuluh. Hal ini dikarenakan penyuluh masih mengalami kesulitan untuk mengidentifikasi satu persatu potensi yang ada. Kendala ini yang menyebabkan kerja dari penyuluh kurang maksimal.

Indikator yang memiliki skor tertinggi 2,39 kategori "berperan" yaitu evaluasi terhadap kegiatan kelompok tani, hal ini membuktikan bahwa penyuluh sudah melakukan evaluasi terhadap kelompok tani tersebut. Dimana evaluasi dilakukan penyuluh sebelum dilakukannya panen oleh petani untuk memantau kegiatan kelompok tani yang di dapat oleh petani dari suatu kegiatan sangat penting, dilaksanakan untuk mengukur sejauh mana peningkatan terhadap perkembangan kegiatan yang dilaksanakan oleh petani untuk perkebunan kakao yang dimiliki oleh petani tersebut.

\section{7) Persepsi Petani Terhadap Peran Penyuluh Sebagai Evaluasi}

Evaluasi dapat dilakukan pada sebelum (formatif), selama (on going) dan setelah kegiatan selesai dilakukan (sumatif, ex-post). Pada Tabel 10 dapat dilihat bahwa persepsi anggota terhadap peran penyuluh sebagai evaluasi memiliki rata-rata 2,84 dengan kategori "berperan". Hal ini terlihat dengan kinerja penyuluh yang telah berjalan dengan baik. Evaluasi yang dilakukan oleh penyuluh akan berpengaruh terhadap kinerja petani.

Tabel 10. Persepsi petani terhadap peran penyuluh sebagai evaluasi

\begin{tabular}{clll}
\hline No & \multicolumn{1}{c}{ Persepsi anggota } & Skor & Kategori \\
\hline 1. & $\begin{array}{l}\text { Membantu kelompok tani membuat laporan perkembangan } \\
\text { perkebunan kakao } \\
\text { 2. }\end{array}$ & 2,93 & Berperan \\
\hline & Remberikan penilaian terhadap keberhasilan kelompok tani & 2,75 & Berperan \\
\hline
\end{tabular}

Sumber : Olah Data (2014

Item yang memiliki kategori paling tinggi yaitu membantu kelompok tani membuat laporan perkembangan perkebunan kakao dengan skor 2,93 dengan kategori "berperan", hal ini melihat perkembangan petani dalam hal seperti proses penanama, pemupukan, pemanenan, dan penyemproan apabila kakao terkena hama dan penyakit, dari laporan tersebut penyuluh telah melakukan kerjanya dengan baik untuk membantu petani dengan mengevaluasi setiap kegiatan. Evaluasi harus terus dilaksanakan untuk meningkatkan kualitas perkebunan kakao.

Indikator paling rendah terdapat pada memberikan penilaian terhadap keberhasilan kelompoktani dengan skor 2,75 kategori 
"berperan". Ini jelas terlihat dari keberhasilan penyuluh dalam memberikan penilaian. Meskipun belum maksimal, tetapi ini telah berjalan cukup baik untuk menjadikan perkebunan kakao lebih maju.

Program kerja kelompok tani yang tidak terlaksana pada tahun 2013 dengan terserangnya penyakit pada setiap perkebuan kakao yang dimiliki oleh petani, dan penyakit tersebut menyebar yang mengakibatkan gagalnya panen kakao terbesar saat itu. Permasalahan itu mengakibatkan pergantian program yang dibimbing langsung oleh penyuluh dari IPB (Institut Pertanian Bogor) dan ini biasanya akan dilanjutkan untuk program kerja di tahun berikutnya. Penilaian yang dilakukan penyuluh akan menjadi acuan ke depannya bagi Gapoktan untuk memperbaiki apa yang belum terlaksana dan mengevaluasi kendala-kendala yang dihadapi selama menjalankan program kerja.

\section{b. Rekapitulasi Persepsi Petani Terhadap Peran Penyuluh}

Dalam penelitian ini penilaian dilakukan dengan mengumpulkan dari semua skor penilaian petani dari jumlah angka yang diperoleh. Hal ini bertujuan untuk mengetahui skor maksimal prestasi kinerja penyuluh dari masing-masing rekapitulasi persepsi petani terhadap peran penyuluh terhadap perkembangan program WKP di Kenagarian Sundata. Rekapitulasi Persepsi Petani Terhadap Peran Penyuluh dapat dilihat pada tabel 11.

Tabel 12. Rekapitulasi Persepsi Petani Terhadap Peran Penyuluh

\begin{tabular}{clrc}
\hline No & \multicolumn{1}{c}{ Persepsi peran penyuluh } & Skor & Kategori \\
\hline 1. & Sebagai Diseminasi informasi/inovasi & 2,28 & Kurang Berperan \\
2. & Sebagai Edukasi & 2,32 & Kurang Berperan \\
3. & Sebagai Pendamping & 2,40 & Berperan \\
4. & Sebagai konsultan & 2,87 & Berperan \\
5. & Sebagai pembinaan & 2,66 & Berperan \\
6. & Sebagai Pemantau & 2,37 & Berperan \\
7. & Sebagai Evaluasi & 2,84 & Berperan \\
\hline & Jumlah & 17,74 & Berperan \\
\hline
\end{tabular}

Sumber: Data Olahan (2014)

Pada Tabel 11, persepsi terhadap peran penyuluh rata-rata mendapat skor 2,53 dengan kategori "berperan" dengan baik. Variabel persepsi peran penyuluh dinilai dari sub variabel yaitu peran penyuluh sebagai edukasi, sebagai diseminasi informasi/inovasi, sebagai pendamping, sebagai konsultan, sebagai pembinaan, sebagai pemantau dan sebagai evaluasi. Peran penyuluh sebagai edukasi diperoleh skor 2,32 dengan kategori "kurang beperan", diamana persepsi peran penyuluh sebagai edukasi masih belum terlihat dampaknya dalam meningkatkan edukasi para petani atau belum memberikan dampak nyata terhadap peningkatan edukasi pada petani kakao rakyat, hal ini dikarenakan penyuluh tidak melakukan kunjungan kepada petani, dan minimnya materi yang diberikan penyuluh kepada petani ini mengakibatkan minimnya informasi yang diterima oleh penyuluh.
Peran penyuluh sebagai diseminasi informasi/inovasi diperoleh skor 2,28 dengan kategori "kurang beperan" hal ini dikarenakan pendidikan petani yang minim yang membuat petani sulit untuk menerima inovasi terbaru tentang budidaya, dan juga jarangnya penyuluh memberikan bimbingan kepada petani.

Peran penyuluh sebagai pendamping diperoleh skor 2.40 dengan kategori "berperan" hal ini dapat terlihat dari peran penyuluh yang mendampingi petani dalam mengambil keputusan mengenai masalah yang dihadapi petani baik itu yang berkaitan dengan masalah teknis dan non teknis dan juga penyuluh memfasilitasi petani agar lebih mudah memperoleh sarana produksi.

Peran penyuluh sebagai konsultan diperoleh skor 2,87 dengan kategori "beperan", artinya penyuluh sebagai konsultan telah melakukan tugasnya dalam membantu 
memecahkan masalah, memberikan alternatif jawaban tentang masalah yang dihadapi oleh petani, dan juga penyuluh berperan penting dalam penyusunan perkembangan dana pemerintah.

Peran penyuluh sebagai pembinaan diperoleh skor 2,66 dengan kategori "berperan" artinya peran penyuluh sebagai pembinaan penyuluh dan bersama bersama-sama memberikan pembinaan pengelolaan dana WKP kepada petani, dan selalu menjalin kerjasama dengan kelompoktani dan instansi lain untuk meningkatkan SDM petani. Peran penyuluh sebagai pemantau diperoleh skor 2,37 dengan kategori "berperan" artinya bahwa peran penyuluh sebagai pemantau bertugas melakukan pemantauan kepada petani sangat baik sehingga kegiatan petani selalu diawasi oleh penyuluh.

Peran penyuluh sebagai evaluasi diberi skor 2.84 dengan kategori "berperan" artinya bahwa penyuluh sudah menjalankan perannya dengan baik kepada petani misalnya membantu Gapoktan dalam membuat laporan WKP dan selalu memberikan penilaian terhadap keberhasilan kelompoktani.

Peran penyuluh bisa di evaluasikan dengan kategori dengan baik dikerjakan dengan baik oleh para penyuluh dalam meningkatkan kualitas petani terhadap perkembangan perkebunan kakao yang ada di pasaman, kategori yang dimaksud adalah sampainya ilmu yang diberikan langsung kepada petani untuk mengubah pola pikir petani untuk maju dalam perkembangan perkebunan yang petani miliki. Berdasarkan rata - rata dari Rekapitulasi Persepsi Terhadap Peran Penyuluhan 2,53 dengan katagori " berperan". Yang disimpulkan dari Edukasi, Diseminasi, Informasi/Inofatif, Pendamping, Konsultan, Pembinaan, Pemantauan, Evaluasi.

\section{KESIMPULAN}

Berdasarkan hasil penelitian dengan analisis hasil dan pembahasan yang telah dilakukan di Kanagarian Sundata dapat disimpulkan bahwa:

a. Penyelenggaraan penyuluhan di Kanagarian Sundata secara umum dapat dikatakan berjalan dengan baik karena telah sesuai dengan unsur-unsur penyuluhan yaitu dapat dilihat dari: a) Persepsi petani yang berada di Kanagarian Sundata merespon baik tentang penelitian ini. b) Sasaran penyuluhan adalah kelompoktani yang bergabung pada perkebunan kakao di Kanagarian Sundata. c) Metode yang digunakan yaitu dengan cara system acak, wawancara dan diskusi, media penyuluhan. e) Waktu penyuluhan dilakukan setiap hari Senin, Rabu, Kamis, Jumat dengan ketentuan jadwal yang telah disepakati, penyuluhan dilakukan di tempat-tempat berkumpulnya para petani misalnya di kantor kelompok tani atau balai desa.

b. Persepsi petani terhadap peran penyuluh pertanian dalam menjalankan tugasnya dikategorikan "berperan" dengan baik, hal ini dapat dilihat dari skor sebesar 2,53 hal ini dilihat dari tujuh peran penyuluh yang dijadikan penilaian oleh petani. Analisis persepsi petani rakyat bisa dilihat dari beberapa faktor yaitu: sebagai edukasi, sebagai diseminasi informasi/inovasi, sebagai pendamping, sebagai konsultasn, sebagai pembinaan, sebagai pemantau, dan sebagai evaluasi.

c. Rekapitulasi persepsi petani terhadap peran penyuluh jumlah rata-rata dari 7 faktor yaitu 2,53 dengan kategori "berperan" yang terdiri dari persepsi peran penyuluh sebagai edukasi yang memiliki skor 2,32 kategori "tidak berperan", persepsi peran penyuluh terhadap diseminasi/inovasi dengan skor 2,28 kategori "tidak berperan", persepsi peran penyuluh sebagai pendamping dengan skor 2,40 kategori "berperan", persepsi peran penyuluh sebagai konsultan dengan skor 2,87 kategori "berperan, persepsi peran penyuluh sebagai pembinaan dengan skor 2,66 kategori "berperan", persepsi peran penyuluh sebagai pemantau dengan skor 2,37 "berperan", dan persepsi peran penyuluh sebagai evaluasi memiliki skor 2,84 kategori “ beperan”. Terlihat pada 7 faktor ini memiliki skor terendah dengan kategori "tidak berperan" yaitu persepsi peran penyuluh sebagai edukasi dan diseminasi informasi/inovasi, sedangkan persepsi peran penyuluh sebagai pedamping, konsultan, pembinaan,pemantau, dan evaliasi memiliki skor tertinggi dengan kategori "beperan. 


\section{DAFTAR PUSTAKA}

Akbar \& Usman. (2009). Metode Penelitian Sosial. Jakarta: Bumi Aksara.

Damro, L. 2011. Evalusi Pelaksanaan PUAP Pada Kelompoktani Di Kota Pekanbaru. Program Studi Agribisnis Fakultas Pertanian Universitas Riau. Pekanbaru.

Dinas Perkebunan, 2012. Data Kakao Provinsi Sumatera Barat. Pasaman.

Mardikanto, Totok. 2009. Penyuluhan dan Pembangunan Pertanian. Universitas Sebelas Maret Press.

Sugiyono, 2009. Metode Penelitian Administrasi. Alfabeta. Bandung. 